\title{
Traumatic injury among females: does gender matter?
}

\author{
Ayman El-Menyar ${ }^{1,2,3^{*}}$, Hany El-Hennawy ${ }^{4}$, Hassan Al-Thani ${ }^{4}$, Mohammad Asim ${ }^{1}$, Husham Abdelrahman ${ }^{4}$, \\ Ahmad Zarour ${ }^{4}$, Ashok Parchani ${ }^{4}$, Ruben Peralta ${ }^{4}$ and Rifat Latifi ${ }^{4,5}$
}

\begin{abstract}
Background: Trauma remains one of the leading causes of morbidity and mortality worldwide. Generally, the incidence of traumatic injuries is disproportionately high in males. However, trauma in females is underreported.

Aim: To study the epidemiology and outcome of different mechanisms and types of traumatic injuries in women.

Methods: We conducted a traditional narrative review using PubMed, MEDLINE and EMBASE, searching for English-language publications for gender-specific trauma between January 1993 and January 2013 using key words "trauma", "gender", "female" and "women".

Results: Among 1150 retrieved articles, 71 articles were relevant over 20 years. Although it is an important public health problem, traumatic injuries among females remain under-reported.

Conclusion: There is a need for further research and evaluation of the exact burden of traumatic injuries among females together with the implementation of effective community based preventive programs.
\end{abstract}

Keywords: Trauma, Gender, Injury mechanisms, Female

\section{Introduction}

Traumatic injuries are considered a significant burden on healthcare system worldwide. According to National Trauma Institute in US, traumatic injuries accounted for $30 \%$ of all life years lost in the 2009 [1]. The effect of traumatic injuries on life years lost is equivalent to the life years lost from cancer, cardiovascular disease (CVD) and HIV together. Trauma is the third leading cause of death among all age groups and the mortality rate is exceptionally high particularly among young age group [1]. Moreover, the annual incidence of burn-related mortalities exceeds 300,000 worldwide [2]. A recent report from Qatar showed that the burden of diseases among men was found three times more than of women's [3]. For men, chronic diseases like CVD (15.7\%) and motor vehicle crashes (MVCs) (13.7\%) represent a great burden and an important source of lost years of healthy life. Generally, women are under-representative in all kind of

\footnotetext{
* Correspondence: elmenyar@yahoo.com

${ }^{1}$ Clinical Research, Trauma Surgery Section, Hamad General Hospital, PO Box 3050, Doha, Qatar

${ }^{2}$ Clinical Medicine, Weill Cornell Medical School, Doha, Qatar

Full list of author information is available at the end of the article
}

studies including non-trauma medical disorders due to socio-cultural barriers [4-6]. However, women sustaining traumatic injuries should have true representation of the disease burden, as it needs acute interventions. Despite that, there is a lack of relevant literature on the incidence of trauma involving female gender. We reviewed all the relevant studies from our institute during the last 5 years period (Table 1) [3,7-18]. In these studies, representation of females was very low in comparison to males. Does this observation represent the true care provided to females and does it influence the healthcare approach to and the strategy for females? We do not have a clear answer.

To focus on the incidence, characteristics, mechanism, risk factors, outcome and preventive strategies for trauma in females, we conduct a traditional narrative review of the literature utilizing the search engines: PubMed, MEDLINE and EMBASE by using key words "trauma", "gender", "female", and "women" between January 1993 and January 2013. We excluded abstracts and non-English articles. The review included trauma regardless the severity, mechanism of injury, hospital complications and outcomes. Among 1150 articles, 71 articles were relevant. 
Table 1 Studies from our institute during the last 5 years (traumatic and non-traumatic)

\begin{tabular}{lll}
\hline Authors & Studies & Female/Male \\
\hline El-Menyar et al. [7] & Chest injury & $6 \% / 94 \%$ \\
AbdulRahman et al. [8] & Multiple rib fracture & $7.3 \% / 92.7 \%$ \\
El-Menyar et al. [9] & Traumatic abdominal injury & $7 \% / 93 \%$ \\
Faramawy et al. [10] & Traumatic spinal injury & $8 \% / 92 \%$ \\
Moamena et al. [11] & Traumatic head injury & $8 \% / 92 \%$ \\
Abdulrazzaq et al. [12] & Pedestrians injury & $8.1 \% / 91.9 \%$ \\
Zarour et al. [13] & Diaphragmatic injury & $16 \% / 84 \%$ \\
Tuma et al. [14] & Fall from height & $0 \% / 100 \%$ \\
Atique et al. [15] & Fall of heavy objects & $3 \% / 97 \%$ \\
Bener et al. [3] & Measuring burden of diseases & $24.5 \% / 75.5 \%$ \\
Latifi et al. [16] & Pedestrian injuries & $7 \% / 93 \%$ \\
El-Menyar et al. [17] & Acute Coronary Syndrome & $24 \% / 76 \%$ \\
Al-Thani et al. [18] & Peripheral arterial disease & $35 \% / 65 \%$ \\
\hline
\end{tabular}

The majority of articles were traumatic brain injuryfollowed by pregnancy - related trauma. Therefore, although it is an important public health problem, traumatic injuries among females remain under-reported.

\section{Incidence and mechanism of traumatic injuries Motor Vehicle Crash (MVC)}

The annual incidence of MVC-related mortality is about 1.24 million worldwide [19]. More than three-quarters (77\%) of all road traffic deaths occur among men. Also, the fatality rate increased three-folds among young males ( $<25$ years of age) compared to young females [19]. This could be explained by greater exposure of driving and patterns of high risk behavior in males $[20,21]$. In many developed countries, there is high incidence of pedestrian mortality among males. According to WHO report, males involving in pedestrian fatalities accounted for $70 \%$ and $61 \%$ in US and Singapore, respectively [22]. Among child pedestrians involving MVC, boys are usually involved in more incidents than young girls. This is because boys are more likely than girls to cross roads unaccompanied by an adult [22] Traffic collisions involving children on bicycles report higher fatality rates for boys. The incidence of mortality was two times higher for boys using bicycles compared to girls [22]. In elderly population, the rate of mortality from MVC was two-three folds higher in males than elderly females in developing countries [22]. With respect to MVC-related injuries, women are at a greater risk of injuries to lower extremities particularly ankle/tarsal injuries due to smaller stature [22]. According to a recent report from US, female occupants (aged 20-35 yrs) of motor vehicles were $28-31 \%$ more susceptible for fatal injuries than males from similar crash due to smaller body stature [22].

Further, gender differences might impact the social and economic consequences of injury-related temporary and/or permanent disabilities. Women may typically not be in jobs that have an adequate insurance coverage or allow for long duration of absence from work. They may not be able to pay for home-based nursing care, and for childcare and paid domestic help that may be needed because of their temporary or permanent impairment. On the other hand, as men are often the sole income earners in many families, injury-related disabilities may affect the overall household economy to a greater extent [22].

Notably, in most of the gulf region, driving license is difficult for females and this may in part explain the lower rate of MVCs among females. Moreover, the traditional female dressing in that region of the world may explain in part the pedestrian injuries in females.

\section{Gender and fall}

Falls are a serious public health concern worldwide. It is the second major cause of fatal unintentional injuries, subsequent to MVCs [23]. In particular, a higher frequency $(80 \%)$ of fall-related deaths has been reported from developing countries. The highest rate of fallrelated mortality is observed among older age group (>60 yrs) [23]. Generally, men and women are at equal risk of fall related injuries, irrespective of age groups and regions (Figure 1). However, fall-related mortality rates are highest among males in the low and middle-income countries [24]. Whereas, the incidence of nonfatal fallsrelated injuries is more common in women compared to men [25]. Older women and younger children are more susceptible to falls and sustained severe injuries [23].

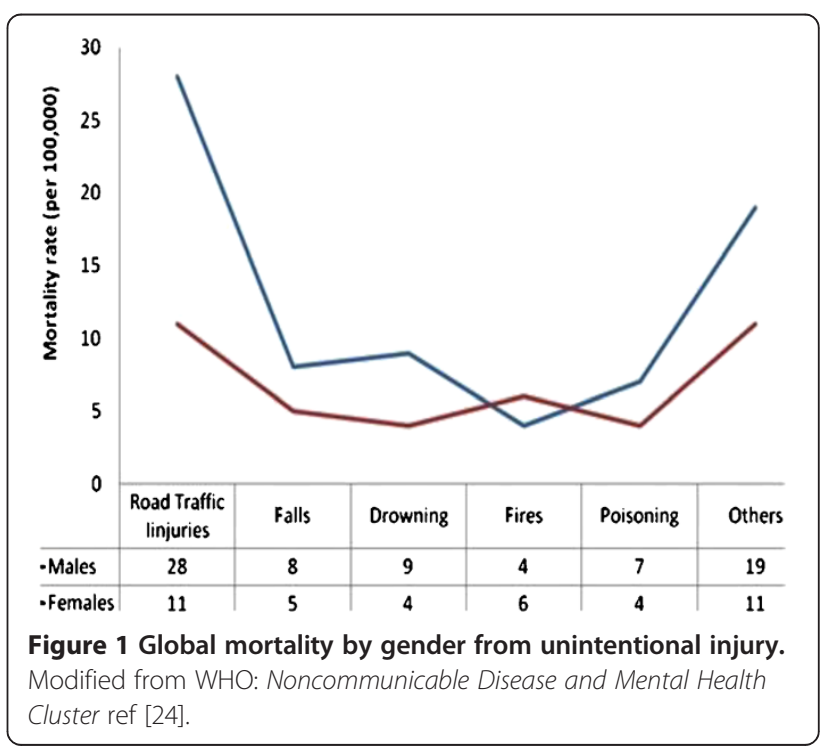


However, higher levels of risk-taking behaviors and occupational hazards are the key factors associated with increased mortality and DALYs among males [23]. Further, falls may be associated with fracture. Among the US community-dwelling elderly, low-impact falls lead to half a million osteoporotic fractures per year [26]. The major risk factors for fracture included age, female gender, menopause before age of 45 and visual impairment [27]. Kantayaporn et al. [27] reported visual impairment in elderly women is highly associated with fall-related fractures. Also, in comparison to men, older women had two times higher rates of fall-related fractures [28]. The majority (95\%) of hip fractures are caused by falls [29]. According to National Center for Health Statistics, hip fractures in women are three times higher than men. Also black women have significantly lower risk of hip fracture compared to white women [30]. An increased risk of fall is also observed in relation to living environment such as slippery floor in the house and bathroom/ toilet located outside the house [31]. Contrarily, elderly people living with spouse had a $32 \%$ lesser chance of experiencing a fall compared to those who lived alone [31]. Stevens \& Dellinger showed a significant increase in fall-related death rates among whites in US, with an annual increase of $3.6 \%$ for men and $3.2 \%$ for women, respectively [32].

\section{Gender and burn}

Burns remains serious public health concern which accounts for an annual mortality of 310,000, globally in 2004 [33]. Low- and middle-income countries represents majority of these fatalities (4.8 per 100,000 per year). It is evident that women and young children are at greater risk of domestic burns. Several studies have reported female gender to be at high risk of mortality in burn injuries [34-36]. Also, females are at high risk for the development of hypertrophic scarring after burn injury [37].

In the acute phase of burn injuries, pediatric females have reasonably higher levels of anabolic hormones than the male patients, thereby sustaining decreased hypermetabolism and need shorter intensive care unit stay [38]. In another subsequent study, Jeschke et al. [39] showed that females have shorter intensive care units (ICUs) and hospital stay than males after severe thermal injury. This is because, females who sustained burns exert an attenuated inflammatory and hypermetabolic response than males. Better ICU prognosis in females with improved muscle protein net balance, preserved lean body mass and reduced resting energy expenditure prediction was reported in females when compared to males [38].

A study based on a large population of burn injury patients (34,470 men and 14,609 women) showed that women had a $50 \%$ increased risk of death when compared to men. Also, age stratification showed higher risk of mortality among females of all age groups between 10 and 70 years [40]. In contrast, Barrow et al. and Kobayashi et al. found no significant difference in mortality rate by genders among severely burned children and adults, respectively [41,42]. McGwin et al. [43] concluded that a significant correlation was observed between mortality and gender with respect to age. Mortality rate among females of $<60$ years was over twice that of males, however, no difference was noted among those $>60$ years. These associations persisted following adjustment for potentially confounders. Therefore, women of $<60$ years of age with burn injuries have an increased risk of death compared with males.

\section{Trauma in pregnancy}

In the United States, trauma is the leading cause of maternal morbidity and mortality [44]. Trauma accounted for most of the non-obstetric mortalities among young women of 14 and 44 years in the study by Mighty [45]. The incidence of traumatic injury varies from $6 \%$ to $7 \%$ among pregnant women [46] and most injuries are minor, therefore the rate of hospitalization is only $0.3 \%$ to $0.4 \%$ [47]. Pregnancy is associated with a number of physiological and anatomical changes, that may be expected to increase the morbidity and mortality among women who sustain injury during pregnancy $[48,49]$. However, the influence of hormone levels had considerable effect on outcome in post trauma pregnant women. John et al. [44] observed lower mortality among pregnant women in comparison to the females of the same age groups with equal injury severity. This study suggested a possible role of hormonal and physiologic status during pregnancy in improved trauma outcomes [44].

Mendez-Figueroa et al. [50] found that domestic violence, partner violence and MVC are the predominant causes of reported trauma during pregnancy [50]. Similarly, Shah et al. [51] stated that around 70\% of injuries in pregnant women are related to MVCs followed by due to domestic violence (12\%). George et al. [52] found high injury severity scoring (ISS) and abdominal abbreviated injury score (AIS), longer hospital and intensive care LOS, high incidence of intubation and placenta abruption to be significantly associated with unsuccessful pregnancy. The reported incidence of placental abruption is $1 \%$ to $5 \%$ in minor injuries and $20 \%$ to $50 \%$ in major injuries, with all abruptions occurring within 6 hours of trauma [53,54]. Women delivering at the trauma hospitalization had the worst outcomes, regardless the severity of the injury and should be monitored closely during the subsequent pregnancy [55]. Management of trauma during pregnancy should be focused on maternal stabilization which depends upon severity of 
traumatic injuries [50]. The study of Scorpio et al. [56] showed fetal outcome is significantly associated with ISS and admission serum bicarbonate levels of the pregnant women after trauma. Moreover, fetal outcome is not affected by surgery or diagnostic peritoneal lavage and these procedures should not be delayed, if indicated [56].

\section{Trauma in elderly women}

Falls remains the major cause of non-fatal injuries in geriatric trauma with progressively increasing rates of mortality. Over a period of ten years, the mortality among geriatric falls raised to $45.3 \%$ and $59.5 \%$ in men and women, respectively [57]. Fractures, open wounds, contusions, sprains/strains, and traumatic brain injury (TBI) are the frequently observed injuries in falls. Especially, older women are more prone to trauma due to co-morbidities, such as osteoporosis. Osteoporosis severely affects older women who are at high risk of hip fracture [58]. The incidence of hip fractures is disproportionately higher in women than men [29]. The medical cost in management of these injuries is high due to the need of surgery, hospitalization, and extensive rehabilitation [59]. Moreover, women with chronic medical conditions or functional impairments are at higher risk of subsequent traumatic injuries [60]. However, in US, according to NHTSA report, the incidence of elderly women involving in MVCs is equivalent to the elderly men [61].

\section{Females and fragility fractures}

Due to the decrease in oestrogen production after the menopause, females are at a greater risk of osteoporosis than males [62]. The number of females with osteoporosis increases from $2 \%$ at age 50 to $>25 \%$ at age 80 [62]. Osteoporosis is often asymptomatic in its early stage until fracture happens. Fragility fractures are fractures that result from mechanical forces (low energy trauma) that would not result in fracture under normal situation [63]. Fragility fractures are associated with substantial disability, reduced quality of life and excess mortality in older people [62].

Hip fracture, a common example of fragility fractures, always requires hospitalization and is fatal in $20 \%$ of patients. Moreover, it permanently causes disabilities in $50 \%$ of affected patients as only $30 \%$ of patients fully recover [63]. The frequency of low energy pelvic fracture admissions in patients $>50$ years old has been shown to increase by $58 \%$ and $111 \%$ in males and females, respectively [64]. An audit from Ireland showed that females accounted for $75 \%$ of hip fractures that on average occur 7 years earlier in comparison to males [62]. The 1 -month mortality was $7 \%$, whereas 1 -year mortality was $22.6 \%$ for females and $27.8 \%$ for males [62]. For a long time, the majority of fragility pelvic fractures were managed conservatively and prior studies showed a lower mortality and morbidity with early aggressive surgical management of neck of femur fractures when compared with delayed or conservative management [64]. It has been noted that the outcomes are similar regardless of the displacement or fracture type [64]. However, there are no randomized comparative studies comparing operative to conservative management in fragility fractures of the pelvis.

\section{Females and home trauma}

According to the Monash University Accident Research Centre [65], home is the second location, after transport, of fatal injuries to adult females accounting for $45 \%$ of home injury hospital admissions (HIHA). Also, sixtyeight percent of hospital admission related to home injury constituted elderly women ( $>60$ years).

Falls cause the majority of HIHA followed by intentional self-inflicted injury. The peak times for home injuries are from Saturday to Wednesday (inclusive) and in the summer months. According to Victorian Coroners' Facilitation System data, $56 \%$ of reported home injury adult female deaths are intentional. Women aged $>55$ years had 1.5 times increased risk of all-cause mortality compared to young women in house-hold injuries [65].

\section{Gender differences and trauma pathophysiology}

Several studies have identified gender as a factor influencing complication rates and outcomes after traumatic injury [66-69]. The possible explanation for this heterogeneity is the differential effects of sex steroids such as anabolic or catabolic steroids [70,71]. Therefore, post injury pathogenesis varies significantly according to gender [72]. There is also difference in the physiological response to injury between men and women. HoustonBolze et al. [73] reported an increase in the insulin-like growth factor (IGF)-1 concentration and little change in transthyretin levels with the increase in the severity of injury in women. In contrast, the levels of IGF-1 and transthyretin decrease with increasing injury severity among men. Another study by Ertan et al. [74] found significantly higher levels of plasma interleukin-1beta levels among male with trauma hemorrhage than female patients. Also, post-trauma, female patients had significantly shorter ICU stay than males because of higher anabolic hormones levels, which causes decreased proinflammatory response and hypermetabolism [75]. Moreover, there is a gender-specific variability among blood glucose levels in trauma patients which could be used a predictor of outcome. Mohr et al. [76], reported an increased association between blood glucose variability and mortality rate among males. A study based on major burn trauma, showed that post-injury myocardial 
function and myocardial inflammatory responses are gender-specific [77].

\section{Gender differences in trauma immunopathology}

Traumatic injuries patients generally had suppressed immune functions due to severe hemorrhage. Moreover, young men, ovariectomized and elderly women are reported to have severe immunosuppression [78]. However, females sustaining traumatic hemorrhage in premenopausal age have maintained immune functions and better prognosis. Therefore, it is evident that sex hormones are crucial for maintaining the host immune response in trauma patients. Besides cytokine production, immune cells also express receptors for androgen and estrogen. Therefore, cytokine production is modulated by local production of active steroids in immune cells [78]. Choudhry et al. [72] described beneficial effect of female sex hormone on immunomodulation. Whereas, male sex steroids suppresses immune and cardiac functions in hemorrhagic trauma patients. A study based on animal model showed gender-specific suppression of cell-mediated immune response after burn injury [79]. The investigators reported lower T-helper 1 cytokine production in males than in female mice. These findings suggest that the level of steroid hormones at the time of injury correlates well with the outcome of trauma.

\section{Gender and outcome}

Some studies analyzing traumatic injuries have identified gender-specific differences in the outcome [80]. George et al. [81] found a significant association between male patients of increased age ( $>50 \mathrm{yrs})$ and mortality after blunt trauma. Mostafa et al. [80] observed higher incidence of multiple organ failure, longer intensive care unit and hospital LOS, and higher mortality in young males in comparison to females. Napolitano et al. [68] found no association between gender and mortality in blunt trauma patients who did not develop pneumonia. Moreover, patients who developed pneumonia had 2.8 to 5.6 fold increased risk of mortality among females compared to males. Rappold et al. [82] also found no protective effect of female gender on the development of ARDS, pneumonia, sepsis, or lower mortality after blunt trauma. In burn trauma patients, the risk of mortality was doubled among women aged 30-59 years than in men of similar age group [83]. Trauma related to low falls exhibited greater survival benefits with respect to pre-existing conditions and male gender [84].

Studies have suggested differential response of nervous system towards traumatic brain injury (TBI) in male and female gender. According to Ottochian et al. [67], female gender and increased age ( $\geq 55$ yrs) are independent predictors of mortality in isolated severe TBI patients. Kraus et al. [85] reported a hospital mortality difference of $28 \%$ between females and males as multivariate analysis demonstrated that females were 1.75 times more likely to die than males. Farace and colleagues [86] conducted a meta-analysis and reported worse outcomes for females. On the other hand, Leitgeb et al. [87] could not find any effect of gender on outcomes after TBI. Moreover, functional outcome in head injury patients lacks significant correlation between male and female gender [88].

\section{Strategies for prevention of traumatic injury among women}

Strategies focusing gender-specific risk factors are imperative for injury prevention. Awareness campaigns for safer driving and working conditions should be launched publically. School-age children and adolescents of both genders should be targeted. Older men and women are highly susceptible for trauma, therefore, supportive environment for geriatric populations is needed during in-door and out-door activities. Injury prevention programmes should focus on building positive behavioral change in the community through public awareness and educational events. Planning rehabilitation services for trauma patients should consider gender differences in the socioeconomic consequences of temporary and/or permanent disability post injury.

Prevention of domestic falls especially among elderly women should be emphasized through effective fall prevention programs which include creating safer environments, education and training in geriatric population [23]. Community based fall prevention programs should include identification and management of potential risk factors, such as screening for living environments; clinical interventions to identify risk factors, like treatment of low blood pressure, Vitamin D and calcium supplementation, treatment of correctable visual impairment. Home assessment and environmental modification are essential for individuals with known risk factors or a history of falling. Prescription of appropriate assistive devices to address physical and sensory impairments; muscle strengthening and balance retraining prescribed by a trained health professional are needed for community-based group programs. Mass counseling regarding safety, proper clothing to be worn at time of cooking and first aid measures are essential for burn injury prevention.

It is recommended to improve the safety of all road users. However, special focus should be given to improve car and street designs for more safety and visibility. In addition, educational programs should improve the safety of older people in road traffic [89].

\section{Summary \& conclusion}

There is considerable effect of gender on the traumatic injury outcome. This could be explained by the anatomical, physiological, immunological and hormonal differences 
which play an important role in the gender-specific trauma outcome. In almost all types and mechanism of injuries, the frequency of male gender is disproportionately high and masks the impact of trauma in female population $[90,91]$. Further research should emphasize the main causes of Injury, differences in treatment, complications, and long term outcomes among females. So, there is a need of extensive research for evaluation of exact magnitude of traumatic injuries in women together with effective implementation of community based preventive interventional programs.

\section{Competing interests}

The authors declare that they have no competing interests.

\section{Authors' contributions}

AE carried out data analysis and interpretation, drafted and reviewed the manuscript. HE participated in data analysis, interpretation, and helped to draft the manuscript. HA was involved in study design, data collection and review of the manuscript. MA participated in data analysis, coordination and helped to draft the manuscript. HA conceived of the study, participated in its design and review of the manuscript. AZ participated in the study design, data interpretation, and helped to review the manuscript. AP involved in the study design, data interpretation, and drafted the manuscript. RP participated in study design, data interpretation, and helped to draft the manuscript. RL conceived of the study, and participated in its design, data interpretation, and reviewed the manuscript. All authors read and approved the final manuscript.

\section{Acknowledgement}

All authors read and approved the manuscript with no conflict of interest and no financial issue to disclose.

\section{Author details}

'Clinical Research, Trauma Surgery Section, Hamad General Hospital, PO Box 3050, Doha, Qatar. ${ }^{2}$ Clinical Medicine, Weill Cornell Medical School, Doha, Qatar. ${ }^{3}$ Internal Medicine, Ahmed Maher Teaching Hospital, Cairo, Egypt. ${ }^{4}$ Trauma Surgery Section, Hamad General Hospital, Doha, Qatar. ${ }^{5}$ Department of Surgery, Arizona University, Tucson, AZ, USA.

Received: 11 March 2014 Accepted: 22 July 2014

Published: 28 July 2014

\section{References}

1. Centers for Disease Control and Prevention, National Center for Injury Prevention and Control: Web-based Injury Statistics Query and Reporting System (WISQARS) [online]. Atlanta, GA: Retrieved from http://www.cdc.gov/ injury/wisqars/ Accessed April 11, 2012.

2. Torpy JM: Burn injuries. JAMA 2009, 302(16):1828. http://www.jama. jamanetwork.com/article.aspx?articleid=18478643. Road traffic injuries, WHO Fact sheet N³58, March 2013. http://www.who.int/mediacentre/factsheets/ fs358/en/, last access 24/03/2013.

3. Bener A, Zirie MA, Kim EJ, Al Buz R, Zaza M, Al-Nufal M, Basha B, Hillhouse EW, Riboli E: Measuring burden of diseases in a rapidly developing economy: state of Qatar. Glob J Health Sci 2012, 5(2):134-144.

4. Makama JG, Garba ES, Ameh EA: Under representation of women in surgery in Nigeria: by choice or by design? Oman Med J 2012, 27(1):66-69.

5. Hoel AW, Kayssi A, Brahmanandam S, Belkin M, Conte MS, Nguyen LL: Under-representation of women and ethnic minorities in vascular surgery randomized controlled trials. J Vasc Surg 2009, 50(2):349-354.

6. Jagsi R, Motomura AR, Amarnath S, Jankovic A, Sheets N, Ubel PA: Under-representation of women in high-impact published clinical cancer research. Cancer 2009, 115(14):3293-3301.

7. El-Menyar A, Latifi R, AbdulRahman H, Zarour A, Tuma M, Parchani A, Peralta R, al Thani H: Age and traumatic chest injury: a 3-year observational study. Eur J Trauma Emerg Surg 2013, doi:10.1007/s00068-013-0281-7.
8. Abdulrahman H, Afifi I, El-Menyar A, Al-Hassani A, Almadani A, Al-Thani H, Latifi R: Clinical outcomes of multiple rib fractures: does age matter? Eur J Trauma Emerg Surg 2013, 39:605-611. doi:10.1007/s00068-013-0291-5.

9. El-Menyar A, AbdulRahman $\mathrm{H}$, al Thani $\mathrm{H}$, Zarour A, Tuma M, Parchani A, Peralta R, Latifi R: Traumatic Blunt Abdominal Injury from the anatomical piont of view. Lyon, France: Presented at 14th Eur Cong Trauma \& Emerg Surg; 2013.

10. El-Faramawy A, El-Menyar A, Zarour A, Maull K, Riebe J, Kumar K, Mathew J, Parchani A, Al-Thani H, Latifi R: Presentation and outcome of traumatic spinal fractures. J Emerg Trauma Shock 2012, 5(4):316-320.

11. El-Matbouly M, El-Menyar A, Al-Thani H, Tuma M, El-Hennawy H, Abdulrahman H, Parchani A, Peralta R, Asim M, El-Faramawy A, Zarour A, Latifi R: Traumatic brain injury in qatar: age matters- insights from $\mathrm{A} 4$-year observational study. Scientific World Journal 2013: doi:10.1155/2013/354920.

12. Abdulrazzaq H, Zarour A, El-Menyar A, Majid M, Al Thani H, Asim M, Latifi R, Maull K: Pedestrians: the daily underestimated victims on the road. Int $J$ Inj Contr Saf Promot 2012. [Epub ahead of print] PubMed PMID: 23194603.

13. Zarour A, El-Menyar A, Al-Thani H, Scalea TM, Chiu WC: Presentations and outcomes in patients with traumatic diaphragmatic injury: a 15-year experience. J Trauma Acute Care Surg 2013, 74(6):1392-1398.

14. Tuma MA, Acerra JR, El-Menyar A, Al-Thani H, Al-Hassani A, Recicar JF, Al Yazeedi W, Maull KI: Epidemiology of workplace-related fall from Height and cost of trauma care in Qatar. Int J Crit Illn Inj Sci 2013, 3(1):3-7.

15. Atique S, Zarour A, Siddiqui T, El-Menyar A, Maull K, Al Thani H, Latifi R: Trauma caused by falling objects at construction sites. J Trauma Acute Care Surg 2012, 73(3):704-708.

16. Latifi R, El-Menyar A, Al-Thani H, Zarour A, Parchani A, Abdulrahman H, Asim M, Peralta R, Consunji R: Cultural aspect of pedestrian injuries amongst expat workers in Qatar: An opportunity for an injury prevention program. Qatar Foundation Annual Research Forum Proceedings. Vol. 2012, BMP74. doi:10.5339/qfarf.2012.BMP74.

17. El-Menyar A, Zubaid M, Rashed W, Almahmeed W, Al-Lawati J, Sulaiman K, Al-Motarreb A, Amin H, R S, Al Suwaidi J: Comparison of men and women with acute coronary syndrome in six Middle Eastern countries. Am J Cardiol 2009, 104(8):1018-1022.

18. Al-Thani HA, El-Menyar A, Zubaid M, Rashed WA, Ridha M, Almahmeed W, Sulaiman K, Al-Motarreb A, Amin H, Al Suwaidi J: Peripheral arterial disease in patients presenting with acute coronary syndrome in six middle eastern countries. Int J Vasc Med 2011, 2011:815902. doi:10.1155/2011/815902.

19. Road traffic injuries, WHO Fact sheet No358, March 2013. http://www.who.int/ mediacentre/factsheets/fs358/en/, last access 24/03/2013.

20. Northern Ireland Statistics and Research Agency (NISRA): 2009 Mid-year population estimates. 2010. http://www.nisra.gov.uk/demography/default. asp17.htm.

21. Office for National Statistics (ONS): Mortality statistics Deaths registered in 2009 Tables 1 and 5.19. 2010. http://www.statistics.gov.uk/downloads/ theme_health/dr2009/dr-09.pdf.

22. World Health Organization: Gender and Road Traffic Injuries. 2002. http://www. who.int/gender/other_health/en/gendertraffic.pdf. last access 24/03/2013.

23. WHO FALL Fact sheet N³44, October 2012. http://www.who.int/mediacentre/ factsheets/fs344/en/ last access 24/03/2013.

24. WHO, D.o.la.V.P: Noncommunicable Disease and Mental Health Cluster, The Injury Chart Book. Fall-related injuries. Geneva, Switzerland: World Health Organization; 2002.

25. Yoshida S: A Global Report on Falls Prevention Epidemiology of Falls. http:// www.who.int/ageing/projects/1.Epidemiology\%20of\%20falls\%20in\%20older \%20age.pdf.

26. Morrison A, Fan T, Sen SS, Weisenfluh L: Epidemiology of falls and osteoporotic fractures: a systematic review. Clinicoecon Outcomes Res 2013, 5:9-18.

27. Kantayaporn C: Fall with and without fracture in elderly: what's different? J Med Assoc Thai 2012, 95(Suppl 10):S109-S112.

28. Donald IP, Bulpitt CJ: The prognosis of falls in elderly people living at home. Age Ageing 1999, 28:121-125.

29. Stevens JA, Sogolow ED: Gender differences for non-fatal unintentional fall related injuries among older adults. Inj Prev 2005, 11:115-119.

30. National Hospital Discharge Survey (NHDS): National Center for Health Statistics. Available at: www.cdc.gov/nchs/hdi.htm. Assessed September 14, 2011.

31. Sophonratanapokin B, Sawangdee Y, Soonthorndhada K: Effect of the living environment on falls among the elderly in Thailand. Southeast Asian J Trop Med Public Health 2012, 43(6):1537-1547. 
32. Stevens JA, Dellinger AM: Motor vehicle and fall related deaths among older Americans 1990-98: sex, race, and ethnic disparities. Inj Prev 2002, 8:272-275

33. World Health Organization: The Global Burden of Disease: 2004 Update. Geneva: World Health Organization; 2008. www.who.int/healthinfo/ global_burden_disease/GBD_report_2004update_full.pdf (Accessed on April 02, 2010).

34. Attia AF, Sherif AA, Mandil AM, Massoud MN, Abou-Nazel MW, Arafa MA Epidemiological and sociocultural study of burn patients in Alexandria, Egypt. East Mediterr Health J 1997, 3(3):452-461.

35. Groohi B, Alaghehbandan R, Lari AR: Analysis of 1089 burn patients in province of Kurdistan. Iran Burns 2002, 28(6):569-574.

36. Estahbanati HK, Kashani PP, Ghanaatpisheh F: Frequency of Pseudomonas aeruginosa serotypes in burn wound infections and their resistance to antibiotics. Burns 2002, 28(4):340-348

37. Lawrence JW, Mason ST, Schomer K, Klein MB: Epidemiology and impact of scarring after burn injury: a systematic review of the literature. J Burn Care Res 2012, 33(1):136-146

38. Jeschke MG, Mlcak RP, Finnerty CC, Norbury WB, Przkora R, Kulp GA Gauglitz GG, Zhang XJ, Herndon DN: Gender differences in pediatric burn patients: does it make a difference? Ann Surg 2008, 248(1):126-136.

39. Jeschke MG, Przkora R, Suman OE, Finnerty CC, Mlcak RP, Pereira CT, Sanford AP, Herndon DN: Sex differences in the long-term outcome after a severe thermal injury. Shock 2007, 27(5):461-465.

40. Kerby JD, McGwin G Jr, George RL, Cross JA, Chaudry IH, Rue LW 3rd: Sex differences in mortality after burn injury: results of analysis of the national burn repository of the American burn association. $J$ Burn Care Res 2006, 27(4):452-456.

41. Barrow RE, Przkora R, Hawkins HK, Barrow LN, Jeschke MG, Herndon DN: Mortality related to gender, age, sepsis, and ethnicity in severely burned children. Burns 2005, 23:485-487.

42. Kobayashi $K$, Ikeda $H$, Higuchi R, Nozaki M, Yamamoto Y, Urabe M, Shimazaki S, Sugamata A, Aikawa N, Ninomiya N, Sakurai H, Hamabe Y, Yahagi N, Nakazawa H: Epidemiological and outcome characteristics of major burns in Tokyo. Burns 2005, 31(Suppl 1):S3-S11.

43. McGwin G Jr, George RL, Cross JM, Reiff DA, Chaudry IH, Rue LW 3rd: Gender differences in mortality following burn injury. Shock 2002, 18(4):311-315.

44. John PR, Shiozawa A, Haut ER, Efron DT, Haider A, Cornwell EE 3rd, Chang $D$ : An assessment of the impact of pregnancy on trauma mortality. Surgery 2011, 149(1):94-98.

45. Mighty H: Trauma in pregnancy. Crit Care Clin 1994, 10:623-634.

46. Peckham $\mathrm{CH}$, King RA: A study of intercurrent conditions observed during pregnancy. Am J Obstet Gynecol 1963, 87:609-624.

47. Lavin JP, Polsky SS: Abdominal trauma during pregnancy. Clin Perinatol 1983, 10:423-438.

48. Esposito TJ: Trauma during pregnancy. Emerg Med Clin North Am 1994, 12:167-199

49. Nash P, Driscoll P: ABC of major trauma: trauma in pregnancy. BMJ 1990, 301:974-976.

50. Mendez-Figueroa H, Dahlke JD, Vrees RA, Rouse DJ: Trauma in pregnancy: an updated systematic review. Am J Obstet Gynecol 2013, doi:0.1016/j. ajog.2013.01.021.

51. Shah KH, Simons RK, Holbrook T, Fortlage D, Winchell RJ, Hoyt DB: Trauma in pregnancy: maternal and fetal outcomes. J Trauma 1998, 45(1):83-86.

52. George ER, Vanderkwaak T, Scholten DJ: Factors influencing pregnancy outcome after trauma. Am Surg 1992, 58:594-598.

53. Dahmus MA, Sibai BM: Blunt abdominal trauma: are there any predictive factors for abruptio placentae or maternal-fetal distress? Am J Obstet Gynecol 1993, 169:1054-1059.

54. Kettel LM, Branch DW, Scott JR: Occult placental abruption after materna trauma. Obstet Gynecol 1988, 71:449-453.

55. El-Kady D, Gilbert WM, Anderson J, Danielsen B, Towner D, Smith LH: Trauma during pregnancy: an analysis of maternal and fetal outcomes in a large population. Am J Obstet Gynecol 2004, 190(6):1661-1668.

56. Scorpio RJ, Esposito TJ, Smith LG, Gens DR: Blunt trauma during pregnancy: factors affecting fetal outcome. J Trauma 1992, 32(2):213-216.

57. Chu I, Vaca F, Stratton S, Chakravarthy B, Hoonpongsimano, Lotfipour S: Geriatric trauma care: challenges facing emergency medical services. Cal J Emerg Med 2007, VIII(2 May):51-55.

58. Melton $\sqcup J 3$ rd, Chrischilles EA, Cooper C, Lane AW, Riggs BL: How many women have osteoporosis? J Bone Min Res 1992, 7:1005-1010.
59. Marks R, Allegrante JP, Ronald MacKenzie C, Lane JM: Hip fractures among the elderly: causes, consequences and control. Ageing Res Rev 2003, 2:57-93.

60. Gerald McGwin MS, May AK, Melton SM, Reiff DA, Rue LW: Recurrent trauma in elderly patients. Arch Surg 2001, 136(2):197-203.

61. The Crash Outcome Data Evaluation System (CODES), U.S. Department of Transportation, National Highway Traffic Safety Administration: 1996. http:// www.nhtsa.gov/people/injury/research/connecticut/evalofelderlydrv.html.

62. The prevention and management of fragility fractures in northern Ireland: Report of the fragility fracture working group (June 2009). http://www.nos.org. uk/netcommunity/document.doc?id=529. Last accessed 6 June 2014

63. Osteoporosis: assessing the risk of fragility fracture. 2012. http://www.nice.org. uk/nicemedia/live/13857/60399/60399.pdf. Last accessed 6 June 2014.

64. Quansah B, Stammers J, Sivapathasuntharam D, Culpan P, Bates P: Fragility fractures of the pelvis in the elderly population. Hard Tissue 2013, 2(1):2.

65. Cassell E, Ozanne-Smith J: Women's Injury In The Home. Monash University Accident Research Centre. 1999. http://www.monash.edu.au/miri/research/ reports/muarc158.html. Accessed at 25 April 2013.

66. Deitch EA, Livingston DH, Lavery RF, Monaghan SF, Bongu A, Machiedo GW: Hormonally active women tolerate shock-trauma better than do men Ann Surg 2007, 246:447-455.

67. Ottochian M, Salim A, Berry C, Chan LS, Wilson MT, Margulies DR: Severe traumatic brain injury: is there a gender difference in mortality? Am J Surg 2009, 197:155-158.

68. Napolitano LM, Greco ME, Rodriguez A, Kufera JA, West RS, Scalea TM: Gender differences in adverse outcomes after blunt trauma. J Trauma 2001, 50:274-280

69. Hsieh YC, Frink M, Choudhry MA, Bland Kl, Chaudry IH: Metabolic modulators following trauma sepsis: Sex hormones. Crit Care Med 2007, 35:S621-S629.

70. Knöferl MW, Diodato MD, Angele MK, Ayala A, Cioffi WG, Bland Kl, Chaudry $\mathrm{H}$ : Do female sex steroids adversely or beneficially affect the depressed immune responses in males after trauma-hemorrhage? Arch Surg 2000, 135:425-433.

71. Llompart-Pou J, Raurich J, Al Ibanez J: Relationship between plasma adrenocorticotropin hormone and intensive care unit survival in early traumatic brain injury. J Trauma Inj Infect Crit Care 2007, 62:1457-1461.

72. Choudhry MA, Bland $\mathrm{Kl}$, Chaudry $\mathrm{H}$ : Gender and susceptibility to sepsis following trauma. Endocr Metab Immune Disord Drug Targets 2006, 6(2):127-135.

73. Houston-Bolze MS, Downing MT, Sayed AM, Meserve LA: Gender differences in the responses of serum insulin-like growth factor-1 and transthyretin (prealbumin) to trauma. Crit Care Med 1996, 24(12):1982-1987.

74. Ertan T, Keskek M, Kilic M, Gocmen E, Oguz H, Aksaray S, Koc M: Effects of gender difference in early cytokine levels in trauma patients. Bratis/ Lek Listy 2007, 108(3):128-132.

75. Jeschke MG, Barrow RE, Mlcak RP, Herndon DN: Endogenous anabolic hormones and hypermetabolism: effect of trauma and gender differences. Ann Surg 2005, 24(5):759-767.

76. Mohr AM, Lavery RF, Sifri ZC, Anjaria DJ, Koernig R, Eitch EA, Livingston DH: Am Gender differences in glucose variability after severe trauma. Surg 2010, 76(8):896-902.

77. Horton JW, White DJ, Maass DL: Gender-related differences in myocardial inflammatory and contractile responses to major burn trauma. Am J Physiol Heart Circ Physiol 2004, 286:H202-H213.

78. Choudhry MA, Bland Kl, Chaudry $\mathrm{H}$ : Trauma and immune response effect of gender differences. Injury 2007, 38(12):1382-1391.

79. Plackett TP, Gamelli RL, Kovacs EJ: Gender-based differences in cytokine production after burn injury: a role of interleukin-6. J Am Coll Surg 2010 210:73-78.

80. Mostafa G, Huynh T, Sing RF, Miles WS, Norton HJ: Thomason MH Gender-related outcomes in trauma. J Trauma 2002, 53(3):430-434.

81. George RL, McGwin G, Metzger J, Chaudry $H$, Rue LW: The association between gender and mortality among trauma patients as modified by age. J Trauma 2003, 54(3):464-471.

82. Rappold JF, Coimbra R, Hoyt DB, Potenza BM, Fortlage D, Holbrook T, Minard G: Female gender does not protect blunt trauma patients from complications and mortality. J Trauma 2002, 53(3):436-441.

83. O'Keefe GE, Hunt JL: Purdue GF - An evaluation of risk factors for mortality after burn trauma and the identification of gender-dependent differences in outcomes. J Am Coll Surg 2001, 192(2):153-160. 
84. Hannan EL, Mendeloff J, Farrell LS, Cayten CG: Murphy JG - Multivariate models for predicting survival of patients with trauma from low falls: the impact of gender and pre-existing conditions. J Trauma 1995, 38(5):697-704

85. Kraus JF, Peek-Asa C, McArthur D: The independent effect of gender on outcomes following traumatic brain injury: a preliminary investigation. Neurosurg Focus 2000, 15(8(1)):e5.

86. Farace $\mathrm{E}$, Alves WM: Do women fare worse? A metaanalysis of gender differences in outcome after traumatic brain injury. Neurosurg Focus 2000, 8(1):e6.

87. Leitgeb J, Mauritz W, Brazinova A, Janciak I, Majdan M, Wilbacher I, Rusnak M: Effects of gender on outcomes after traumatic brain injury. J Trauma 2011, 71(6):1620-1626.

88. Yu AH, Cheng $\mathrm{CH}$, Yeung JH, Poon WS, Ho H, Chang A, Rainer TH: Functional outcome after head injury: comparison of 12-45 year old male and female hormonally active patients. Injury 2012, 43(5):603-607.

89. Ytterstad B: The Harstad injury prevention study: community based prevention of fall-fractures in the elderly evaluated by means of a hospital based injury recording system in Norway. J Epidemiol Community Health 1996, 50:551-558.

90. Rodrigues J, Ciosak SI: Elderly victims of trauma: analysis of the risk factors. Rev EsC Enferm USP 2012, 46(6):1400-1405.

91. Dandona R, Kumar GA, Raj TS, Dandona L: Patterns of road traffic injuries in a vulnerable population in Hyderabad. India Inj Prev 2006, 12(3):183-188.

doi:10.1186/1752-2897-8-8

Cite this article as: El-Menyar et al:: Traumatic injury among females: does gender matter? Journal of Trauma Management \& Outcomes 2014 8:8.

\section{Submit your next manuscript to BioMed Central and take full advantage of:}

- Convenient online submission

- Thorough peer review

- No space constraints or color figure charges

- Immediate publication on acceptance

- Inclusion in PubMed, CAS, Scopus and Google Scholar

- Research which is freely available for redistribution 